\title{
Local Soybean Development Strategy In North Sumatra
}

\section{Strategi Pengembangan Kedelai Lokal di Sumatera Utara}

\author{
Leni Handayani \\ Program Studi Agribisnis, Fakultas Pertanian \\ Universitas Muslim Nusantara Al Washliyah \\ Email. lenihandayani@umnaw.ac.id
}

\begin{abstract}
The rapid import of soybeans at low prices makes the domestic soybean market dominated by imported soybeans. This makes the local soybean farmers more squeezed so that the enthusiasm of farmers to grow soybeans is reduced. The purpose of this study is how the strategy of developing local soybean agribusiness in North Sumatra. The method in this study is to use a SWOT analysis to determine the internal and external factors of soybean agribusiness conditions in North Sumatra. The SWOT analysis is carried out using a SWOT matrix and produces four alternative strategies that are able to clearly illustrate how external opportunities and threats faced by the company and its strengths and weaknesses. The results show that the strategy to increase soybean production in the study area is an aggressive strategy or SO (Strengths - Oppurtunities) strategy, which is to use strength to take advantage of existing opportunities with the following activities: (1). Utilizing Gapoktan support so farmers receive quality seed assistance and add to the experience of farmers in soybean agribusiness (2). Utilizing government support in channeling capital to expand soybean farming land. (3). Utilize average input prices and input availability to increase soybean production.
\end{abstract}

Keywords: Development Strategy, Local Soybean, North Sumatra

\begin{abstract}
Abstrak
Derasnya impor kedelai dengan harga murah membuat pasar kedelai di dalam negeri didominasi oleh kedelai impor. Hal ini yang membuat petani kedelai lokal semakin terhimpit sehingga gairah petani untuk menanam kedelai semakin berkurang. Tujuan penelitian ini adalah bagaimana strategi pengembangan agribisnis kedelai lokal di Sumatera Utara. Metode pada penelitian ini adalah menggunakan analisis SWOT untuk mengetahui faktor internal dan eksternal kondisi agribisnis kedelai di Sumatera Utara. Analisis SWOT dilakukan dengan menggunakan matriks SWOT dan menghasilkan empat alternative strategi yang mampu menggambarkan secara jelas bagaimana peluang dan ancaman eksternal yang dihadapi perusahaan serta kekuatan dan kelemahan yang dimilikinya. Hasil penelitian menunjukkan bahwa strategi untuk meningkatkan produksi kedelai di daerah penelitian adalah strategi agresif atau strategi SO (Strengths - Oppurtunities) yaitu menggunakan kekuatan untuk memanfaatkan peluang yang ada dengan kegiatan sebagai berikut : (1). Memanfaatkan dukungan Gapoktan agar petani memperoleh bantuan benih berkualitas dan menambah pengalaman petani dalam agribisnis usahatani kedelai (2). Memanfaatkan dukungan pemerintah dalam menyalurkan modal untuk memperluas lahan usahatani kedelai. (3). Memanfaatkan harga input rata-rata dan ketersediaan input untuk meningkatkan produksi kedelai
\end{abstract}

Kata Kunci : Strategi Pengembangan, Kedelai Lokal, Sumatera Utara

\section{A. PENDAHULUAN}

Kebutuhan kedelai untuk konsumsi diproyesikan akan meningkat rata-rata 2,44\%/tahun [1]. Dewasa ini kedelai tidak hanya digunakan sebagai sumber protein, tetapi juga sebagai pangan fungsional yang dapat mencegah timbulnya penyakit degenerative seperti penuaan dini, jantung koroner dan hipertensi. Senyawa isoflavon yang terdapat pada kedelai ternyata berfungsi sebagai antioksidan. Beragamnya penggunaan kedelai tersebut menjadi pemicu peningkatan konsumsi kedelai.
Strategi yang tepat dapat menjadi alat untuk menciptakan keunggulan sehingga menciptakan persaingan yang sehat [2]. Menurut Kotler $(1997)^{[3]}$ mengidentifikasi kekuatan dan kelemahan suatu usahatani adalah dengan analisis internal yang merupakan proses yang mana perencanaan strategi mengkaji pemasaran, pengembangan, produksi dan operasinya, sumberdaya usaha, serta faktor keuangan dan akuntansi untuk menentukan dimana suatu usahatani mempunyai kemampuan yang penting, sehingga dapat memanfaatkan peluang dengan cara yang paling efektif dan menangani ancaman dalam lingkungan 
sedangkan dalam lingkungan eksternal dapat menyediakan dasar-dasar bagi petani sebagai pengusaha untuk memanfaatkan peluang dan merencanakan tanggapan yang tepat sesuai dengan peluang yang ada dan juga membantu petani untuk melindungi usahataninya terhadap ancaman.

Konsumsi kedelai lebih difokuskan untuk industri olahan tahu dan tempe, karena menyerap konsumsi terbesar. Menurut Saptana $(1993)^{[4]}$ dan berdasarkan observasi pada industri olahan bahwa industri tahu menginginkan kedelai yang mengandung sari kedelai yang lebih tinggi dan tidak mempermasalahkan ukuran biji. Industri tahu dengan cita rasa khas yang lebih enak.

Menurut Sudaryanto $(2001)^{[5]}$ bahwa kedelai memiliki potensi pasar yang luas di dalam negeri untuk memenuhi kebutuhan pangan dan pakan. Namun, potensi pasar yang besar dan terus berkembang tersebut belum dapat dimanfaatkan secara optimal melalui pengembangan produksi dalam negeri. Pengembangan kedelai menghadapi persoalan teknis, sosial dan ekonomi. Jika kondisi sosial ekonomi kondusif maka secara teknis pengembangan kedelai memiliki potensi dan peluang yang menadai.

Senada dengan Soleh, (1999) ${ }^{[6]}$ menyatakan bahwa produktivitas kedelai dipengaruhi oleh jenis tanah, kualitas benih, varietas, pengelolaan tanaman, takaran pupuk, pengendalian hama dan penyakit, waktu tanam dan panen, teknologi yang digunakan dan interaksi semua faktor tersebut. Kendala non teknis dalam usahatani kedelai adalah ketersediaan modal.

\section{B. METODE PENELITIAN}

Penelitian ini membahas tentang kondisi sistem agribisnis kedelai lokal di Sumatera Utara, dengan menganalisis faktor internal dan faktor eksternal agribisnis kedelai di Sumatera Utara, serta strategi pengembangan yang dapat dihasilkan untuk meningkatkan produksi kedelai lokal. Lingkup penelitian ini meliputi strategi pengembangan kedelai lokal. Waktu penelitian berlangsung dari bulan Oktober hingga Desember 2018. Populasi penelitian sampel adalah petani kedelai yang melakukan usahatani di 2 Kabupaten di Provinsi Sumatera Utara yaitu Kabupaten Langkat dan Deli Serdang. Metode penentuan sampel dilakukan dengan teknik Purposive Sampling yaitu pemilihan sampel secara sengaja dari keseluruhan populasi yang ada dimana setiap sampel yang jumlahnya ditetapkan.

\section{Metode Analisis Data}

Pengolahan dan analisis data dilakukan secara deskiptif kualitatif. Analisis deskriptif kualitatif dilakukan untuk mengetahui gambaran kondisi sistem agribisnis kedelai lokal di Sumatera Utara. Selain itu analisis deskriptif kualitatif juga dilakukan dengan menggunakan metode analisis SWOT digunakan untuk mengetahui strategi pengembangan untuk agribisnis kedelai lokal di Sumatera Utara. Pada penelitian ini terdapat pihak internal dan pihak eksternal. Pihak internal terdapat pada lingkungan mikro, sedangkan pihak eksternal berada pada lingkungan makro. Dari keempat komponen dasar tersebut, Strength (kekuatan) dan Weakness (Kelemahan) adalah faktor internal agribisnis usahatani itu sendiri, sedangkan Opportunities (Peluang) dan Threats (Ancaman) merupakan faktor eksternal yang mempengaruhi perkembangan agribisnis usahatani. Oleh karena itu, Analisis SWOT juga sering disebut dengan Analisis InternalEksternal dan Matriks SWOT juga sering dikenal dengan Matrix IE (Internal-Eksternal Matrix).

\section{HASIL DAN PEMBAHASAN}

Nilai skor faktor kekuatan faktor internal pengalaman petani dalam usahatani memiliki skor sebesar 4 dan bobot sebesar 0,22. Hal tersebut menunjukkan bahwa kondisi eksisting sangat baik dan petani menganggap pengalaman petani dalam usahatani kedelai tinggi sehingga berdampak pada pengembangan agribisnis kedelai.

Faktor internal penguasaan petani terhadap teknik budidaya dalam usahatani kedelai memiliki skor sebesar 4 dan bobot sebesar 0,22. Hal ini menunjukkan bahwa faktor internal penguasaan petani terhadap teknik budidaya dalam usahatani dianggap penting dalam usahatani dan dapat menjadi salah satu faktor untuk pengembangan agribisnis di daerah penelitian, karena dari pengalaman yang dimiliki petani, petani dapat belajar dan menambah kemampuan dalam usahatani kedelai.

Banyaknya industri pengolahan berbahan baku kedelai merupakan faktor internal kekuatan karena memiliki skor sebesar 4 dan bobot sebesar 0,22. Hal ini menunjukkan bahwa kondisi eksisting banyaknya industri pengolahan berbahan baku kedelai sangat baik dan petani menganggap faktor tersebut sangat berpengaruh pada pengembangan agribisnis kedelai.

Faktor internal kekuatan benih yang digunakan dan ketersediaan benih memiliki skor sebesar 3 yang merupakan skor yang baik dalam faktor internal dan memiliki nilai bobot baik 
yaitu sebesar 0,17. Hal ini menunjukkan bahwa bibit kedelai yang digunakan petani sudah baik dan petani menganggap hal tersebut sangat penting.

Faktor internal kekuatan kedelai lokal memiliki masa panen yang lebih pendek dari kedelai impor yang digunakan dan ketersediaan benih memiliki skor sebesar 3 yang merupakan skor yang baik dalam faktor internal dan memiliki nilai bobot baik yaitu sebesar 0,17. Hal ini menunjukkan bahwa kedelai lokal lebih baik dari kedelai lokal dan petani menganggap hal tersebut sangat penting.

Faktor internal kelemahan lahan yang digunakan memiliki skor sebesar 2 dan bobot sebesar 0,18. Artinya adalah lahan yang digunakan cukup sempit, petani menganggap lahan yang digunakan sangat berdampak pada pengembangan agribisnis kedelai.

Modal petani merupakan faktor internal kelemahan karena memiliki skor sebesar 2 dan bobot sebesar 0,22. Hal ini menunjukkan bahwa modal petani tidak memenuhi dalam usahatani kedelai dan petani menganggap faktor tersebut sangat berpengaruh pada pengembangan agribisnis kedelai.

Faktor internal kelemahan yaitu tenaga kerja yang digunakan memiliki nilai skor sebesar 2 dan nilai bobot sebesar 0,18. Hal tersebut menunjukkan bahwa kondisi tenaga kerja yang digunakan kurang baik dan disebabkan oleh karena jumlah tenaga kerja yang dibutuhkan tidak cukup akibat kurangnya biaya untuk mempekerjakan tenaga kerja yang dibutuhkan, akan tetapi keterampilan tenaga kerja tersebut tergolong cukup baik.

Faktor internal kelemahan banyaknya petani yang tidak menggunakan benih yang dianjurkan memiliki skor sebesar 2 dan jumlah bobot sebesar 0,27. Ini menunjukkan kondisi banyaknya petani yang tidak menggunakan benih cukup baik dan faktor ini dianggap penting bagi petani. Petani mengetahui pentingnya penggunaan benih yang dianjurkan untuk pengembangan agribisnis kedelai.

Faktor internal kelemahan yaitu penggunaan pupuk yang belum sesuai anjuran yang digunakan memiliki nilai skor sebesar 2 dan nilai bobot sebesar 0,18. Hal tersebut menunjukkan bahwa kondisi pemberian pupuk yang tidak sesuai anjuran hal ini disebabkan oleh keterbatasan modal petani, hal tersebut dapat menghambat pengembangan agribisnis kedelai.

Faktor internal kelemahan yaitu gairah petani untuk melakukan budidaya kedelai menurn memiliki nilai skor sebesar 2 dan nilai bobot sebesar 0,18 . Hal tersebut menunjukkan bahwa kondisi gairah petani untuk menanam kedelai kurang baik dan disebabkan oleh karena harga kedelai lokal memiliki harga yang rendah, banyaknya impor kedelai, minat konsumen industri lebih menyukai kedelai impor daripada kedelai lokal, hal tersebut dapat menghambat pengembangan agribisnis kedelai.

Total skor terbobot kekuatan adalah sebesar 3,66 dimana nilai tersebut lebih besar jika dibandingkan dengan total skor terbobot faktor kelemahan yaitu sebesar 2,25. Selisih skor terbobot faktor kekuatan dengan faktor kelemahan yaitu sebesar 1,41. Selisih skor terbobot tersebut merupakan nilai $\mathrm{x}$, yang akan menentukan posisi pengembangan agribisnis kedelai dalam matriks posisi SWOT.

Faktor eksternal peluang permintaan kedelai di daerah penelitian memiliki nilai skor 4,00 dan bobot 0,24 yang berarti kondisi eksisting permintaan kedelai sangat baik dan dianggap cukup penting oleh petani.

Faktor eksternal peluang harga input rata-rata memiliki skor 3,00 dan bobot 0,19 yang artinya harga input usahatani (bibit, pupuk, pestisida dan obat-obatan) rata-rata yang diterima petani cukup baik dan dianggap penting bagi petani. Petani mengetahui pentingnya penggunaan input usahatani sesuai rekomendasi dosis namun sebagian petani tidak mengetahui pentingnya penggunaan input usahatani sesuai rekomendasi waktu.

Faktor eksternal peluang dukungan Gapoktan memiliki skor sebesar 3,00 dan bobot sebesar 0,19. Hal ini menunjukkan bahwa eksisting Dukungan Gapoktan adalah baik dan faktor ini dianggap penting bagi petani. Keterbatasan modal dan kemampuan yang dimiliki petani, menyebabkan petani sangat membutuhkan Dukungan Gapoktan yang dapat digunakan petani.

Faktor eksternal peluang Dukungan Pemerintah memiliki skor sebesar 3,00 dan nilai bobot sebesar 0,19. Hal ini menunjukkan bahwa kondisi Bantuan Pemerintah adalah baik dan petani menganggap bantuan pemerintah sangat penting dalam pengembangan agribisnis kedelai. Petani mengharapkan adanya bantuan yang berkelanjutkan dari pemerintah.

Faktor eksternal peluang banyaknya penelitian dan pengembangan kedelai lokal yang sudah dilakukan dan di aplikasikan memiliki skor sebesar 3,00 dan nilai bobot sebesar 0,19. Hal ini menunjukkan bahwa pentingnya penelitian dan pengembangan kedelai lokal cukup baik dan petani menganggap penelitian dan pengembangan sangat penting dalam pengembangan agribisnis kedelai. Petani mengharapkan penelitian dan pengembangan terus dilakukan dalam rangka pengembangan agribisnis kedelai di Sumatera Utara. 
Faktor eksternal ancaman harga jual kedelai di tingkat petani memiliki skor sebesar 2.00 dan bobot sebesar 0,20. Hal ini menunjukkan bahwa kondisi harga jual kedelai di tingkat petani kurang baik dan harga jual dianggap sangat penting bagi petani.

Faktor eksternal ancaman infrastruktur dan sarana pendukung agroindustri memiliki skor sebesar 2,00 dan nilai bobot sebesar 0,20. Hal ini menunjukkan bahwa kondisi infrastruktur dan sarana pendukung agroindustri kurang baik, namun dianggap penting oleh petani. Sarana transportasi umum belum memadai dan agroindustri kedelai yang dikelola secara bermitra masih belum ada, akan tetapi kondisi jalan sudah beraspal.

Faktor eksternal ancaman Dukungan Tenaga Pendamping Penyuluh Pertanian memiliki nilai skor sebesar 2,00 dan bobot sebesar 0,20. Hal ini menunjukkan bahwa tenaga pendamping atau penyuluh di daerah penelitian telah melakukan program dan berkelanjutan akan tetapi sebagian program tersebut tidak berhasil. Hal ini disebabkan karena masih kurangnya pengetahuan Penyuluh Pertanian tersebut dalam pemberantasan hama dan penyakit tanaman kedelai di daerah penelitian.

Faktor eksternal ancaman posisi tawar memiliki nilai skor sebesar 2,00 dan nilai bobot 0,20 . Hal ini menunjukkan bahwa kondisi posisi tawar petani kurang baik. hal ini disebabkan karena usahatani kedelai yang dimiliki petani belum berpola agribisnis dan minimnya informasi pasar di daerah penelitian.

Faktor ekternal ancaman persaingan dengan kedelai impor memiliki nilaiskor sebesar 2,00 dan bobot sebesar 0,20. Hal ini menunjukkan bahwa persaingan terhadap kedelai impor merupakan ancaman yang sangat tidak baik bagi perekonomian petani kedelai lokal. Untuk meningkatkan minat pengusaha industri pengolahan kedelai menggunakan bahan baku kedelai lokal perlu peran serta pemerintah sepenuhny.

Tabel 1. Penggabungan Matriks Evaluasi Faktor Strategi Internal dan Eksternal Pengembangan Agribisnis Kedelai

\begin{tabular}{|c|c|c|c|}
\hline Faktor-Faktor Strategis & Rating & Bobot & Skor \\
\hline \multicolumn{4}{|l|}{ Faktor Strategi Internal } \\
\hline \multicolumn{4}{|l|}{ Strength (Kekuatan) } \\
\hline 1. Pengalaman Petani dalam Usahatani & 4 & 0,22 & 0,88 \\
\hline $\begin{array}{l}\text { 2. Penguasaan Petani Terhadap Teknik Budidaya } \\
\text { Kedelai }\end{array}$ & 4 & 0,22 & 0,88 \\
\hline $\begin{array}{l}\text { 3. Banyaknya Industri Pengolahan Berbahan Baku } \\
\text { Kedelai }\end{array}$ & 4 & 0,22 & 0,88 \\
\hline 4. Benih yang digunakan dan Ketersediaan Benih & 3 & 0,22 & 0,51 \\
\hline \multicolumn{3}{|l|}{ 5. Kedelai Lokal Memiliki Masa Panen yang Lebih } & 0,51 \\
\hline \multicolumn{3}{|l|}{ Weakness (Kelemahan) } & 3,66 \\
\hline 1. Lahan yang digunakan & 2 & 0,18 & 0,36 \\
\hline 2. Modal Petani & 2 & 0,18 & 0,36 \\
\hline $\begin{array}{l}\text { 3. Banyaknya Petani yang tidak Menggunakan Benih } \\
\text { yang dianjurkan }\end{array}$ & 2 & 0,27 & 0,81 \\
\hline \multicolumn{4}{|l|}{ 5. Gairah Petani untuk melakukan Budidaya Kedelai } \\
\hline Menurun & 2 & 0,18 & 0,36 \\
\hline Total Skor Kelemahan & 11 & $\mathbf{1 , 0}$ & 2,25 \\
\hline Selisih (Kekuatan - Kelemahan) & & & 1,41 \\
\hline \multicolumn{4}{|l|}{ Faktor Strategis Eksternal } \\
\hline \multicolumn{4}{|l|}{ Oppurtunity (Peluang) } \\
\hline 1. Permintaan Kedelai & 4 & 0,27 & 1,08 \\
\hline $\begin{array}{l}\text { 2. Harga Input Rata-Rata dan Ketersediaan Input } \\
\text { 3. Dukungan Gapoktan }\end{array}$ & 3 & 0,20 & 0,60 \\
\hline 4. Dukungan Pemerintah & 3 & 0,20 & 0,60 \\
\hline 5. Banyaknya Penelitian Pengembangan Kedelai & 3 & 0,20 & 0,60 \\
\hline Lokal yang Sudah dilakukan dan di Aplikasikan & 3 & 0,13 & 0,26 \\
\hline Total Skor Peluang & 15 & 1,0 & 3.24 \\
\hline Threats (Ancaman) & & & \\
\hline 1. Harga Jual Kedelai & 2 & 0,20 & 0,40 \\
\hline
\end{tabular}


2. Infrastruktur dan Sarana Pendukung Agroindustri

3. Dukungan Tenaga Pendukung Masih Kurang

4. Posisi Tawar

0,40

5. Persaingan dengan Kedelai Lokal

\begin{tabular}{llcl} 
& 2 & 0,20 & 0,40 \\
& 2 & 0,20 & 0,44 \\
\hline Total Skor Ancaman & $\mathbf{1 0}$ & $\mathbf{1 , 0}$ & $\mathbf{2 , 0 0}$ \\
\hline Selisih (Peluang - Ancaman) & & & $\mathbf{3 , 2 4}$ \\
\hline
\end{tabular}

\section{KESIMPULAN}

Strategi untuk meningkatkan produksi kedelai di daerah penelitian adalah strategi agresif atau strategi SO (Strengths Oppurtunities) yaitu menggunakan kekuatan untuk memanfaatkan peluang yang ada dengan kegiatan sebagai berikut : (1). Memanfaatkan dukungan Gapoktan agar petani memperoleh bantuan benih berkualitas dan menambah pengalaman petani dalam agribisnis usahatani kedelai (2). Memanfaatkan dukungan pemerintah dalam menyalurkan modal untuk memperluas lahan usahatani kedelai. (3). Memanfaatkan harga input rata-rata dan ketersediaan input untuk meningkatkan produksi kedelai

\section{Daftar Pustaka}

[1]. Sudaryanto, T dan D.K. Swastika, 2007. Ekonomi Kedelai di Indonsia.hlm 1
- 27. Dalam Sumarno, Suyamto, A, Widjono, Hermato dan H. Kasim (Ed), Kedelai Teknik Produksi dan Pengembangan Tanaman Pangan, Bogor

[2] Rangkuti, F, 2008. Analisis SWOT Teknik Membedah Kasus Bisnis Jakarta : PT. Gramedia Pustaka Utama.

[3] Kotler, P. 1997. Prinsip-Prinsip Manajemen, PT Gramedia

[4] Saptana, 1993. Industri Kecil dan Menengah, Penebar Swadaya, Jakarta

[5] Sudaryanto, dkk, 2001. Perspektif Pengembangan Ekonomi Kedelai di Indonesia Forum Agro Ekonomi 19 (1) $-: 1-20$.

[6] Soleh, 1999. Orientasi Kebijakan Pangan Harus ke Arah Swasembada, Lembaran Bisnis dan Investasi 